УДК: 73.03

ББК: 85.133 (4)

A43

DOI: $10.18688 / \mathrm{aa} 177-5-59$

Anna Baydova

\title{
The Sculpted Recumbent Effigy of Marie Gaudin at the Church of Saint Denis in Amboise: History and Artistic Context
}

We can see nowadays at the church of Saint Denis in Amboise the marble recumbent effigy of a naked woman, usually referred to as "the drowned woman". The human-sized body $(164 \times 30 \times 51 \mathrm{~cm})$ is lying on a drape that covers the head and ankles; the crossed hands at the bottom of the belly are also holding the drape. The head with wavy hair rests on pillows (Ill. 126). The face and the chest of the woman are emaciated, her eyes sunken, her mouth half open. The sculpture is damaged; however, neither the breaks of the nose, chin, and lips nor the tearing of the feet disrupt the overall perception (Fig. 1, Fig. 2). We can notice traces of a previous restoration: the chest has been glued back together. The cracks at the wrists and the rough appearance of the hands may lead us to believe that they are not original [7] (Fig. 3). However, they are the part of the same block of marble than the rest of the sculpture. The archives ${ }^{1}$ and testimonies of the $18^{\text {th }}$ century ${ }^{2}$ indicate that the work has been long exposed to moisture, which would explain the eroded state of the marble, and the corrosion having also affected the lower abdomen and upper legs.

The historiography of the work is quite poor and consists primarily of the $19^{\text {th }}$ century publications. In 1828, in its History of the Touraine until the year 1790 [2, pp. 17-18], Jean-Louis Chalmel assumes that the sculpture comes from the chapel of Notre-Dame of Bondésir at the castle La Bourdaisière near Montlouis-sur-Loire, property of Philibert Babou, an important financier and Superintendent of Finances under Francis I. It would have adorned the tomb of the wife of Babou, Marie Gaudin, or his mother-in-law, Agnès Gaudin. In 1897, Alfred Gabeau publishes an article about this so-called "the drowned woman" sculpture in the Bulletin of the archaeological society of Touraine, in which he reconstructs the history of the work, unfortunately without citing the sources [5, pp.202-216]. The same year, the Abbot Bosseboeuf in Amboise, the Castle, the City and the Canton [1, pp.81-85] also presents the history of the sculpture, mixing documented data (without always citing sources) to historical inaccuracies. However, he contributes a lot to the analysis of the figure by comparing it to the royal tombs at the basilica of Saint Denis, and proposing to attribute it to the Italian sculptor Jean Juste II. He has no doubt that the woman represented in marble is Marie Gaudin. 


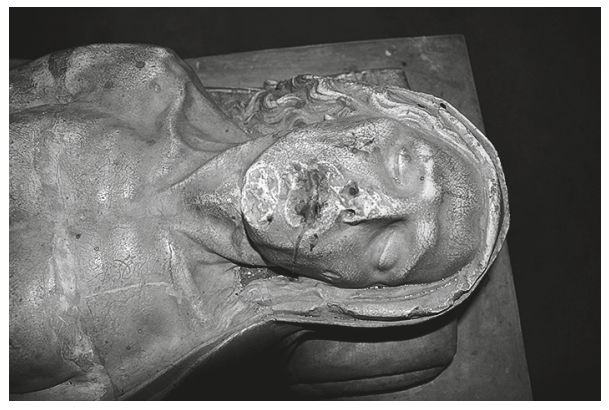

Fig. 1. Face of the recumbent effigy of Marie Gaudin. Second half of the $16^{\text {th }}$ century. Church of Saint Denis in Amboise

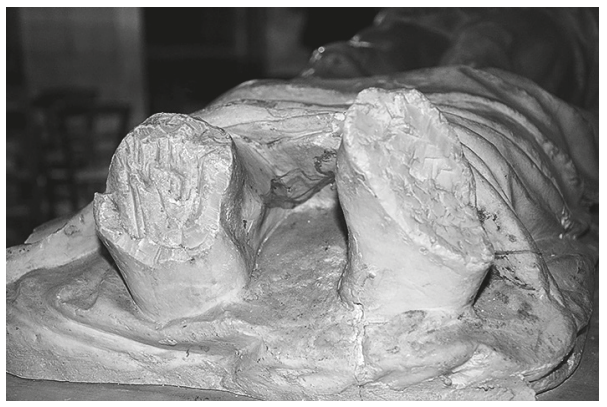

Fig. 2. Broken off feet of the recumbent effigy of Marie Gaudin. Second half of the $16^{\text {th }}$ century. Church of Saint Denis in Amboise

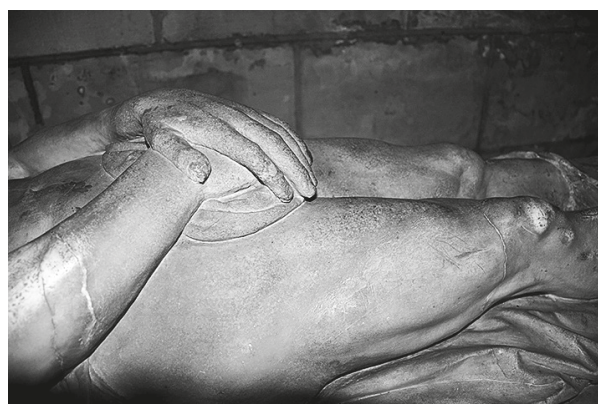

Fig. 3. Hands of the recumbent effigy of Marie Gaudin. Second half of the $16^{\text {th }}$ century. Church of Saint Denis in Amboise "the marble is all green; the moisture of the rocks holding it still wet". still arise in its study.

However, the legend that gave its name to the sculpture is sometimes still included in publications. The identification of the transi with the corpse of a drowned must have appeared at the end of the $18^{\text {th }}$ or early $19^{\text {th }}$ century, just after the transfer of the sculpture at the church of Saint Florentin in Amboise. It is not surprising as the Loire sometimes deposited the bodies of the drowned in the vicinity of the church, built on its banks. The attribution of the sculpture to the Italian painter Primaticcio was added probably a little later and remains more difficult to explain. According to the legend, shocked by the death of his wife, who died during a boat trip on the Loire, he decided to immortalize the terrible vision of her corpse in stone [10, p.XXVI].

Reviewing the approach of Gabeau and Bosseboeuf, it is possible to reconstruct the history of the work, with the supporting archival documentation, replacing it in its historical context without omitting to report the problems that

Most of the authors mention the figure as a funerary sculpture that would come from a tomb of the chapel of Bondésir without delivering their references. In the unpublished notes that Jean-Louis Chalmel drafted for the preparation of his History of Touraine, he quotes a text that describes the sculptures located under the sacristy of this chapel of which one could be the "drowned woman". Resuming this text, for which Chalmel gives no specific source, the Abbot Bosseboeuf attributes it to an anonymous author who would have visited this monument around 1760 [1, pp. 78, 81-82]. Indeed, this testimony must date from before 1770 , because the chapel was closed this year. The description appears all the more faithful because it mentions the bad conditions of preservation of the work, which may explain the corrosion of the stone:

3 ML, Ms. 1219, notebook 5, p. 31 . 
The chapel of Notre Dame of Bondésir was founded by Philibert Babou and Marie Gaudin on April 15, 15444. By this document, they assigned it 20 Tours pounds of annual and perpetual annuity. In his will dated September $9,1557^{5}$, Philibert Babou requested to be buried there. Marie Gaudin expresses the same desire in a document signed in 1564, by which she doubles the assigned annual amount to the chapel (Ill. 127) ${ }^{6}$. She also specifies that her husband and some of her children are already buried at this location. On July 19, 1770, the titles of the chapel of Bondésir, which now belonged to the Duke of Choiseul, were removed and his property, rights, and income passed to the chapter of the church of Saint Florentin in Amboise ${ }^{7}$. On June 21, 1780 , it was decided to demolish the building, which was no longer of any use, in order to reduce maintenance costs, after exhumation of the bodies that had been buried there ${ }^{8}$. Therefore, there is no doubt that the chapel of Bondésir housed the tombs of the family Babou-Gaudin. It was probably during the works of 1780 that the recumbent effigy of "the drowned woman" was relocated. Unfortunately, we don't know of any document explicitly stipulating the tombs, but the testimonies at the beginning of the $19^{\text {th }}$ century indicate the presence of the sculpture at the Saint Florentin church ${ }^{9}$.

In 1864, the sculpture was installed in the castle of Amboise, under control of the Inspector of the Fine Arts Arsène Houssaye, who undertook at the time the excavations there, searching for the tomb of Leonardo da Vinci. Houssaye wanted to expose this sculpture to the visitors of the castle, now the property of the city ${ }^{10}$. During the Franco-Prussian War of 1870-1871, the sculpture was hidden in its basement ${ }^{11}$. In 1894 , we found a testimony of its transfer to the chapel of Saint-Hubert of the castle $\mathrm{e}^{12}$.

However, the ownership of the sculpture was widely debated. In 1873, the Amboise castle was returned to its owner, the Duke of Aumale Henri d'Orléans. In 1890, Louis Courajod, the curator of the sculpture at the Louvre Museum, studied and photographed the work during a visit to Amboise. In a letter to the Director of the Louvre, dated November 21, 1890, he expresses his willingness to bring it into his collections ${ }^{13}$. Indeed, he had learned that the Mayor of the city was ready to give it up in exchange for some tapestries to decorate the new City Hall. The consequences of this case are known thanks to the correspondence between the directorate of the Louvre, Louis Courajod, and the municipality, today preserved in the National Archives of France $^{14}$. During the transition of the Amboise castle in the hands of its new owner, the status of the sculpture was not clarified. This allowed Henri d'Orléans to consider "the drowned woman" as his property, from which he was not willing to separate ${ }^{15}$. The negotiations were complicated by the death of the former Mayor of Amboise and the delays in the selection of his successor.

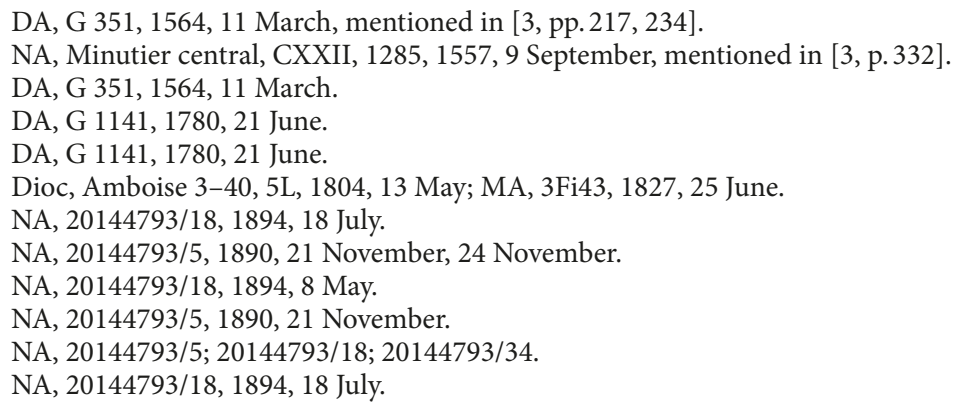


The demands of local scholars were added to these complications. Alfred Gabeau, member of the Archaeological Society of Touraine, and a few other connoisseurs of local history, having learned the intentions of the Louvre Museum, were against the transfer proposal of the sculpture, not wanting to see the region lose a part of its historical heritage. Gabeau thus sent a letter describing the history of the figure called "the drowned woman" to the Duke of Aumale, which he published in his article The Statue of the Drowned Woman in Saint Denis of Amboise in 1897 [5, pp. 204-206]. Hendri d'Orléans, who was risking a lawsuit over this case ${ }^{16}$, met three members of the commission responsible for the restitution of the monument to the city ${ }^{17}$ [5, pp.203-204]. He accepted the restitution of the statue but under the condition that it would never leave Amboise ${ }^{18}$. On October 23, 1896, the latter was returned to the municipality [5, pp. 213-214], which decided the following year to create a hovel in the church of Saint Denis to receive it ${ }^{19}$. The choice of the place is not accidental: The Burial of Christ, also coming from the chapel of Bondésir and considered as a part of the tomb of Philibert Babou, was already in Saint Denis since $1863^{20}$. Thus, the two tombs were again reunited in the southern aisle of the church.

"The drowned woman" was classified historical monument on February 27, 1904. According to the law of March 30,1887, it could not be restored, sold, or moved without an agreement from the French Ministry of Public Instruction and Fine Arts ${ }^{21}$. In 1975, the conservator of the Historical Monuments, Marcel Maimponte, undertook the restoration of The Burial of Christ and a sculpture of the $16^{\text {th }}$ century representing Holy Madeleine, installed since the $19^{\text {th }}$ century beneath a Renaissance Revival canopy on its base plate ${ }^{22}$. He decided to remove the canopy and the metal grid in front of the sculptured ensemble, and to move the figure of Madeleine, which was not originally its part, into the hovel initially created for the recumbent effigy of Marie Gaudin. It is on this occasion that "the drowned woman" was placed on a pedestal in the southern aisle of the $\mathrm{church}^{23}$, where it is still today. The stocktaking of the artworks preserved at the church in Amboise shows that the relocation of "the drowned woman" was detrimental to the state of conservation of the work. Exhibited along the wall of the southern aisle of the building, easy of access for visitors, in a few years it was already showing signs of deterioration. The stocktaking of October 17, 1966 reported it was in fairly good condition, while on August 5, 1978, three years after its move, it was described as being in need of preservation ${ }^{24}$.

Although the history of the work is fairly well documented, information on the original arrangement of the sculptures inside the chapel of Bondésir is lacking. No detailed description or iconographic source allowing us to imagine the building demolished in 1780 is known. Similarly, we do not know when exactly the sculpture was damaged. The old photographs and the casting made by the sculptor Henri Varenne at the time of its transfer to the church of Saint

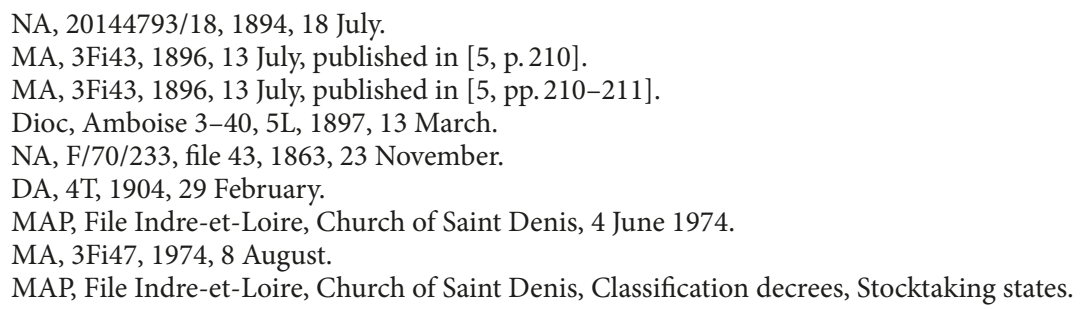


Denis $^{25}$ testify to a poor state of preservation while the work was already at the castle in Amboise, but we don't know the circumstances in which these degradations occurred. According to Gabeau, the effigy could have been vandalized during the Franco-Prussian War and would have been, for this reason, hidden in the basement of the castle, but this assumption is unproven [4, p. 9; 7, p. 22]. However, it should be noted that traces of tools are visible at the place where the feet were broken off.

In the different churches where it was installed, this nude figure apparently caused the embarrassment of the clergy and the faithful. In a letter to the priest of the church of Saint Florentin, written on May 13, $1804^{26}$, Archbishop Jean de Dieu asked for a report on an "indecent statue" displayed in Amboise. After its relocation at the church of Saint-Denis, the Prefect of Indre-et-Loire wrote a letter to the Archbishop of Tours asking him if the presence of the tomb in the church was not an issue. The Archbishop replied that he had taken steps to prevent statue from becoming the object of worship ${ }^{27}$.

The identification of this tomb figure also raised questions. Since its transfer from the chapel of Bondésir, one was looking to understand what historical character it had been intended to. It was even unclear whether it was a man or a woman [4, pp.7-8]. In his letter of June 25, 1827 addressed to the Mayor of Amboise, a so called Blandon de Vierzon, author of several erudite works on the monuments of the city of Bourges and the province of Berry, enumerates all hypothesis to identify the sculpture he knew, mentioning, among others, the Cardinal of Amboise and King Charles VIII, who died in $1498^{28}$. In the correspondence of the Director of the Museum of the Louvre with Louis Courajod and the municipality of Amboise, the statue is regularly called "the drowned man" 29 or "statue of a recumbent man" 30.

The supporters of the hypothesis of a male figure, draw attention to his muscular legs and his large hands, and discern even the Adam's apple. According to Robert Milliat, some have even suggested it to be the statue of beardless Jesus [8] $]^{31}$. Yet, well-sculpted breasts, long curly hair, and the head covered with a drape leave no doubt that it is a female figure. The presence of The Burial of Christ in the chapel of Bondésir confirms it was indeed a funeral chapel and the sculpture of "the drowned woman" could only decorate the tomb of the most important woman of the family, the wife of the founder of the chapel, Philibert Babou, herself donor of Bondésir. Therefore, it is appropriate to abandon this faulty name in favor of its identification as the recumbent effigy of Marie Gaudin. Nevertheless, for lack of detail on this important commission, it seems impossible to date it precisely: if the tomb proved to have been executed after Gaudin's death and not during her lifetime, which was a common practice, it could be dated from the 1580s.

Even if this type of figure is relatively uncommon in France, the recumbent effigy of Marie Gaudin fits perfectly into the typology of the tombs from the second to the last quarter of the

25 Blois, Museum of the Castle of Blois, 32.8.8; 55.190; deposited at the museum after the death of Henri Varenne in 1933.

26 DA, Amboise, 5L, 1804, 13 May.

27 DA, Amboise, 5L, 1897, 15 March.

28 MA, 3Fi43, 1827, 25 June.

29 NA, 20144793/34, 1892, 14 February, 8 March; 20144793/18, 8 May, 18 July.

30 NA, 20144793/34, 1892, 8 March.

31 MA, Amboise, 3Fi43. 
$16^{\text {th }}$ century $[9$, pp. 93-96]. Abbot Bosseboeuf rightly suggested a rapprochement with the Royal recumbent effigies of the basilica of Saint Denis. The tombs of Louis XII and Anne of Brittany by Antoine and Jean Juste (1515-1531) or Francis I and Claude of France by Pierre Bontemps (1558) present indeed the bodies of their occupants. But the closest sculpture of the recumbent effigy of Marie Gaudin is probably a non-finished proposal for the funerary statue of Catherine de' Medici sculpted by Girolamo della Robbia in 1565, today conserved at the Louvre Muse$u^{32}$. The work was rejected because of its striking naturalism ${ }^{33}$ : the dead body is extremely thin, but the calm and peaceful face retains traces of beauty. The two sculptures are comparable: the non-idealized emaciated body, the head with long hair resting on a pillow and turned to the side, the drape covering the lower part of the belly and arranged along the left side of the figure. Among the funeral monuments of the aristocracy, other figures are of the same type, such as the recumbent effigy of Louis de Brézé in the bas-relief of his tomb by Jean Goujon in Rouen $(1535-1544)^{34}$, that of Claude Gouffier by Jean Juste II (Oiron, collegiate 1559), and the effigy in the bas-relief of Valentine Balbiani by Germain Pilon (the Louvre Museum, 1574) [6, vol. 2, p. 527 $]^{35}$. Bosseboeuf attributed the sculpture of Marie Gaudin to Jean Juste II, settled in Tours, not far from the Bourdaisière without giving another argument except the geographic proximity of the places. This very attractive hypothesis is difficult to verify given the destruction of most of his works and the poor state of preservation of the few remaining pieces. The attribution of this work still remains unsure.

The examination of the documents shows that the statue long time called "the drowned woman" is most likely the recumbent effigy of Marie Gaudin, widow of Philibert Babou, Superintendent of Finances under Francis I. The history of the work since its transfer to the Saint Florentin church is quite well specified with the archival documents, but the circumstances of the commission remain unknown, as does the place of the sculpture on the tomb. By its type, this work belongs to the figures of recumbent effigies of the tombs of the aristocracy on the model of the Royal tombs.

\section{References}

1. Bosseboeuf L.A. La Touraine historique et monumentale. Amboise: le château, la ville et le canton. Tours, L. Péricat Publ., 1897. 672 p. (in French).

2. Chalmel J.-L. Histoire de la Touraine jusqu’à l’année 1790, vol.3. Paris; Tours, H. Fournier-A. Mame Publ., 1828. 541 p. (in French).

3. Charton-Le-Clech S. Chancellerie et culture au XVIe siècle (les notaires et secrétaires du roi de 1515 à 1547). Toulouse, Presses Universitaires du Mirail Publ., 1993. 352 p. (in French).

4. Gabeau A. La femme noyée d'Amboise. Pierre tombale de la Renaissance en Touraine. Tours, L. Bousrez Publ., 1896. 16 p. (in French).

5. Gabeau A. La statue de la femme noyée à Saint-Denis d'Amboise. Bulletin de le Société archéologique de Touraine, 1897, vol.11, pp. 202-216 (in French).

6. Gaborit J.-R. (ed.). Musée du Louvre. Département des sculptures du Moyen Âge, de la Renaissance et des temps modernes. Sculpture française. II - Renaissance et temps modernes. Paris, RMN Publ., 1998. 879 p. (in French).

32 Paris, the Louvre Museum, R. F. 1515.

33 There is a hypothesis that the work was not completed due to the death of the author.

34 Rouen, Cathedral.

35 Paris, the Louvre Museum, M. R. 1643. 
7. Godefroy R. La "Noyée d'Amboise”. Courrier d'Amboise, mai 1972, no. 20, pp.21-23 (in French).

8. Milliat R. Les Trésors inconnus, lénigme d'Amboise. L'Echo de Touraine, 9 avril 1984 (in French).

9. Panofsky E. La sculpture funéraire. De l'Egypte ancienne au Bernin. Paris, Flammarion Publ., 1995. 268 p. (in French).

10. Séance du 26 juin 1864. Mémoires de la Société archéologique de Touraine, 1865, vol. 17, p. XXVI (in French).

\section{Archives}

National archives, Paris (NA):

Minutier central, CXXII, 1285; 20144793/5; 20144793/18; 20144793/34.

Departmental archives of Indre-et-Loire, Tours (DA):

G 351; G 1141; 2V83; 5V50; 4T.

Municipal archives, Amboise (MA):

3Fi43; 3Fi47.

Diocesan archives, Tours (Dioc):

Amboise 3-4, 4L ; Amboise 3-40, 5L.

Médiathèque de l'Architecture et du patrimoine, Charenton-le-Pont (MAP):

File: Amboise, Saint Denis.

Municipal library, Tours (ML):

Ms. 1219, notebook 5, pp. 30-31 - the non-published notes of Jean-Louis Chalmel.

\section{Iconographic sources}

National archives, Paris (NA):

20144793/18 - The recumbent effigy of Marie Gaudin in the Hall of States in the castle of Amboise, 3 photographs (before 1896).

Municipal library, Tours (ML):

L. A. TOURAINE (J.-M. Rougé). Amboise. R. 20 - The recumbent effigy of Marie Gaudin in the Hall of States in the castle of Amboise, photograph (before 1896 (ca. 1880)).

The Louvre Museum, Documentation of the Department of Sculptures, Paris:

File Amboise, Indre-et-Loire - The recumbent effigy of Marie Gaudin during its transfer to the Church of Saint Denis in Amboise (?), photograph (between 1896 and 1897 (?)).

Museum of the castle of Blois, Blois:

32.8 .8 ; 55.190 - Henri Varenne, Moulage of the recumbent effigy of Marie Gaudin (1896-1897).

Municipal archives, Amboise (MA):

3Fi43 - The recumbent effigy of Marie Gaudin in its hovel in the southern aisle of the Church of Saint Denis in Amboise, photograph (before 1975).

Médiathèque de l'Architecture et du patrimoine, Charenton-le-Pont (MAP):

37W0036 - The recumbent effigy of Marie Gaudin on a pedestal in the southern aisle of the Church of Saint Denis in Amboise, photograph (after 1975).

\section{Palissy database:}

PM37000006 - Guy du Chazaud, The recumbent effigy of Marie Gaudin on a pedestal in the southern aisle of the Church of Saint Denis in Amboise, photograph (1992).

Article. The Sculpted Recumbent Effigy of Marie Gaudin at the Church of Saint Denis in Amboise: History and Artistic Context.

Author. Anna Baydova - Ph. D. student, study engineer. Centre for Higher Studies of the Renaissance (CESR), 59, rue Néricault-Destouches BP 1205037020 Tours Cedex 1, France. annabaydova@gmail.com

Abstract. The sculpture from the $16^{\text {th }}$ century of a naked woman on her deathbed, preserved at the church of Saint Denis in Amboise, is usually referred to in bibliography as "the drowned woman" and was attributed by local tradition to the Italian painter Primaticcio. This attribution has been challenged for a long time, but the circumstances surrounding the commission remained unknown. The history of this work, moved several times, was revealed by Alfred Gabeau at the end of the $19^{\text {th }}$ century; it can now be completed and clarified by the study of documents and iconographic sources preserved in archives and libraries of France.

The purpose of this article is to identify and to list the historical sources concerning this work, to take stock of its history and to place this funerary monument in its artistic context in order to better understand the 
circumstances of this important commission. The study confirms the identification of the recumbent effigy as a statue of Marie Gaudin, the widow of the rich financier Philibert Babou from Tours. Taking as an example the royal tombs at the basilica of Saint Denis, this commission demonstrates the practices and artistic strategies of the refined aristocracy of the Renaissance.

Keywords: Renaissance; Touraine; Amboise; Church of Saint Denis; sculpture; Marie Gaudin; recumbent effigy; archives.

Название статьи. Скульптурное надгробие Мари Годан в церкви Сен-Дени в Амбуазе: его история и художественный контекст.

Сведения об авторе. Байдова Анна Андреевна - аспирант, научный сотрудник. Центр Высших Исследований Ренессанса (CESR), ул. Нерико-Детуш, 59, Тур Седекс 1, Франция, BP 1205037020. annabaydova@gmail.com

Аннотация. Скульптура XVI века, изображающая обнаженную женщину на смертном одре и ныне хранящаяся в церкви Сен-Дени в Амбуазе, в библиографии традиционно называется «утопленницей» и приписывается итальянскому художнику Приматиччо. Данная атрибуция была давно оспорена, но подробности этого важного заказа до сих пор остаются неизвестными. История этого много раз переносившегося памятника была описана Альфредом Габо в XIX в., но она может быть дополнена и уточнена благодаря документам и иконографическим источникам, хранящимся в архивах и библиотеках Франции.

Основной задачей данного исследования является поиск источников, описывающих историю этого произведения, а также изучение его исторического и художественного контекста, позволяющего лучше понять обстоятельства этого важного заказа. Оно также подтверждает предположение, что скульптура «утопленницы» является надгробным памятником Мари Годан, вдовы богатого финансиста из города Тура. Основываясь на примере королевских надгробий базилики Сен-Дени, этот заказ ярко иллюстрирует художественную стратегию аристократии периода Возрождения.

Ключевые слова: Ренессанс; Турень; Амбуаз; церковь Сен-Дени; скульптура; Мари Годан; скульптурное надгробие; архивы. 


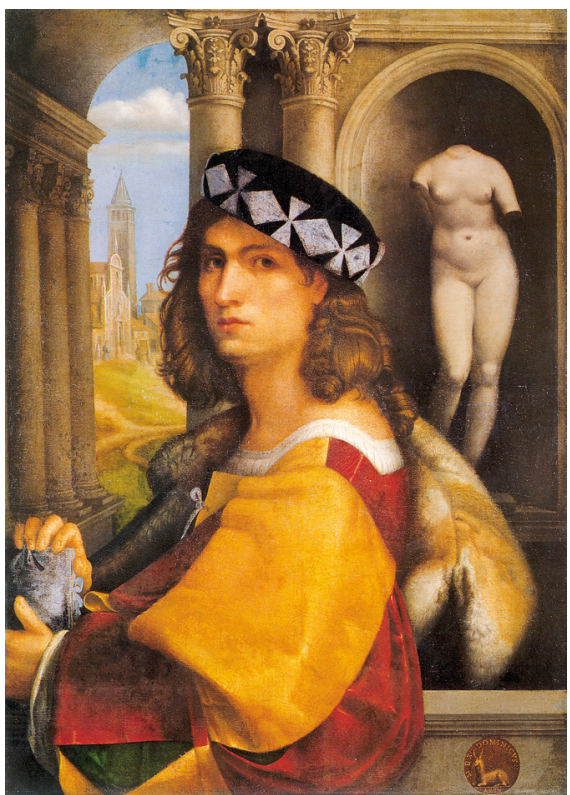

Ill. 124. G. G. Savoldo (attr.). Portrait of Domenico Capriolo from Brescia. 1512. The State Hermitage, St. Petersburg

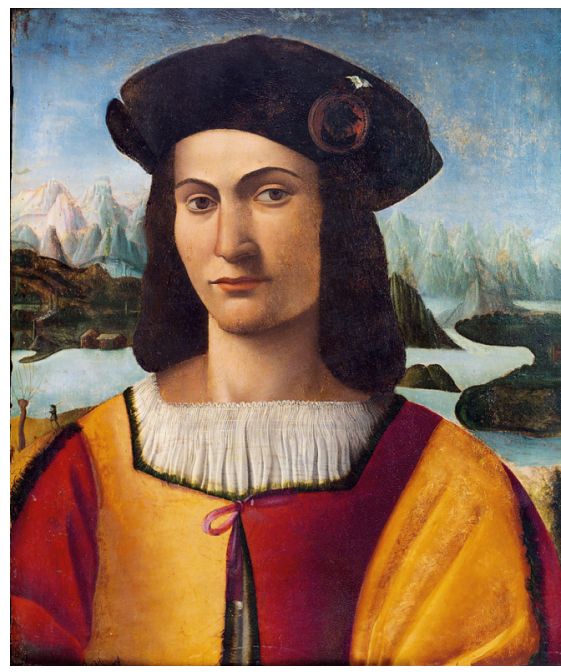

Ill. 125. Anonymous Lombard Painter 1500-1510. Portrait of a member of the Capriolo family against a view of the Lake of Iseo. Philadelphia Museum of Art (John G. Johnson Collection), Philadelphia

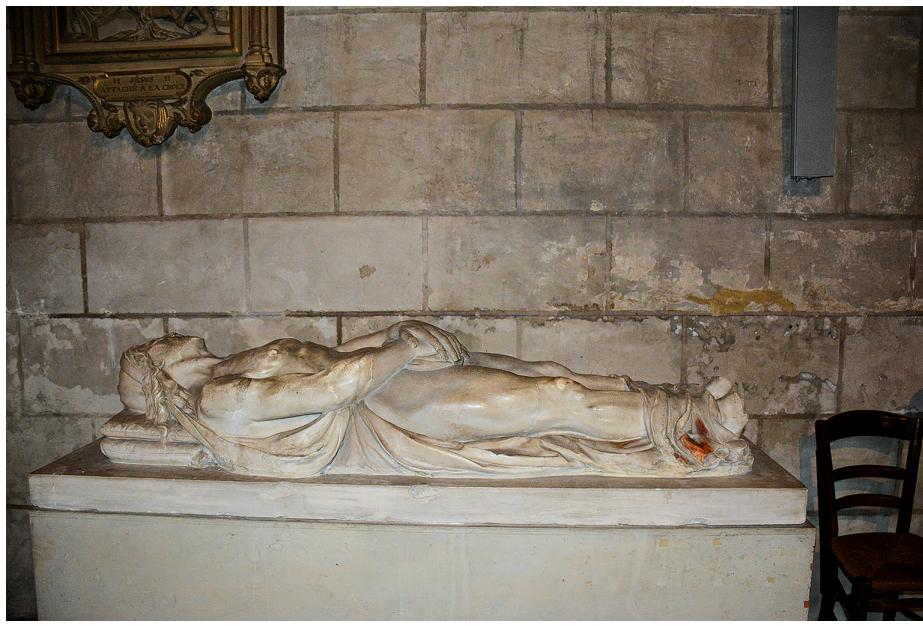

Ill. 126. The recumbent effigy of Marie Gaudin ("the drowned woman"). Second half of the $16^{\text {th }}$ century. Church of Saint Denis in Amboise

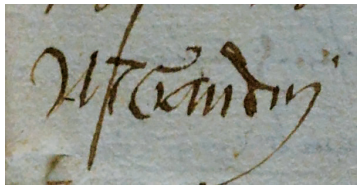

Ill. 127. Signature of Marie Gaudin 